\title{
The Predicament and Egress of China's Higher Education Management in the Era of Globalization
}

\author{
Xu Wang \\ Tianjin University of Finance and Economics, \\ No.25 Zhujiang Road, Hexi District, Tianjin, China \\ E-mail:wangxu587@126.com
}

\begin{abstract}
The internationalization of higher education towards the future is undergoing a series of profound changes. The article from the concept, trends, missions, challenges, and prospects for the five sides. This paper analyzes and expounds the trend and development of the internationalization of higher education in the world and China. In the future, education will be the common cause of the world. The trend of internationalization of higher education will be further accelerated. The internationalization of higher education will be aimed at fostering high-level talents for the future.
\end{abstract}

\section{Keywords: Higher education management, Globalization}

\section{GLOBALIZATION PROMOTES THE MANAGEMENT OF INTERNATIONAL HIGHER EDUCATION'S REFORM AND INNOVATION.}

The development of the times will inevitably affect the reform of higher education management. The globalization era has also put forward a series of new requirements for the management of higher education. Please. These requirements are specifically reflected in the following four aspects:

A. Economic globalization calls for higher education to be strengthened in the management system. Market orientation and speed up the system. The essence of economic globalization is the push of market mechanism on a global scale. The higher education management system refers to standardizing higher education from a macro perspective.

The rule system of management behavior is implemented by the management body. Economic globalization first requires higher education in the design of management system. Strengthen market orientation. The economic globalization has promoted the city of Higher Education. The reform of the market makes the market more closely related to higher education. The market trend of other education is mainly manifested in: the government reduces public funding. Reduce the proportion of higher education funds to GDP; change the channels for higher education institutions. Fee allocation, introducing competition mechanism, holding private colleges and expanding private. Establish the scale of higher education; broaden the funding channels of colleges and universities; implement the tuition policy. And raise tuition fees; motivate universities to transfer technology, Kai Zhanpei. Training, online education and other paid services and recruiting students at their own expense. Overseas education market and so on. The trend of the marketization of higher education is strengthened.

First is the new liberalism, the knowledge commodity concept and the private higher education. The theoretical influence of the concept of product.

B. Cultural diversity requires higher education to strengthen open and inclusive education in the management concept, to realize the economic globalization of independent innovation, to break the cultural pattern of the old world, to break the barriers of cultural closure and cultural isolation, to bring unprecedented great exchanges and conflicts in the global culture, and to present the coexistence of exclusion and integration, assimilation and adherence to the presence of cultural diversity. Cultural pluralism is bound to require higher education with an important function of choice, communication, dissemination and innovation culture, making new adjustments in management philosophy. Cultural pluralism calls for further enhancement of the concept of openness and inclusiveness. Different countries and nationalities have formed their own local culture in their own development history. These cultures are both different and complementary, all of which are the common spiritual wealth of human beings.

Globalization promotes the exchange, collision and integration of all kinds of heterogeneous cultures, and forms a more vigorous world culture and local culture. Universities in all countries should become a melting pot of multiculturalism, so that different cultures can compete, develop freely, learn from each other and improve constantly in universities. At present, the developed countries and regions of higher education do not take the open and inclusive attitude of multiculturalism to absorb the essence of different cultures and form a cultural joint force to promote the development of higher education. In addition to the curriculum, American universities give students and teachers the freedom to promote their own culture in various educational and teaching activities such as the activities of students' cultural associations, thus promoting the students to form an equal interpersonal concept, open global consciousness and continuous innovation ability.

The United States is the most developed country of higher education in the world today. Its development has 
also benefited from the collision and integration of multiculturalism in universities.

C. Information networking requires higher education to establish shared networks and achieve efficient transparency in management mode.

The process of economic globalization and cultural diversity provides a strong demand and power for the formation of information network, and the rapid development of information network provides more advanced technology and means for economic globalization and cultural diversification. The extensive development of information resources and the development of network technology have not only changed the way of the organization and management of the society, but also greatly influenced the management mode of higher education, that is, the main body of higher education management should change the traditional management methods, methods and means.

Information networking requires the establishment of a shared network in the management mode of higher education. The traditional higher education management mode is basically manual operation in the collection, arrangement, analysis and transmission of information, and the efficiency of management is low, and the speed and breadth of the management information transmission is very limited. The network information technology makes modern higher education management free from the restriction of traditional manual operation, realizes the automation of management information collection, and intelligentize information analysis, and makes information release and acquisition break through time and space restrictions, so that people can realize communication and communication anytime and anywhere, in order to establish the school of higher education management information. International and even international sharing networks have laid the foundation for technology. In recent years, the international and regional higher education quality information sharing network has been established in order to realize the international sharing of higher education quality and guarantee information.

Information networking also calls for increasing the transparency of information in higher education and improving the efficiency of management. The transcending time and space of information transfer draws closer to the distance between the managers and the administrators of higher education, enlarges the public's right to know and participates in the process of management, and objectively requires the transparent and transparent process of the management of higher education. One of the important principles of WTO for trade activities among members, including higher education services, is to ensure the openness and transparency of relevant regulations, systems and commodity information. For example, in cross-border higher education, educational exporting countries and importing countries all attach importance to information collection and publicity. With the globalization of information and network, the management model of higher education in the world is becoming more and more public, democratic, scientific and standardized, which has greatly improved the efficiency of higher education management.

D. Decentralization requires higher education to reduce government intervention and expand university autonomy in the management system.

The management system of higher education, also known as the administrative management system of higher education, mainly refers to the management and supervision of various forms of higher education by governments at all levels, which mainly reflects the power division of the three main bodies of University, government and society on the allocation of higher education resources. The tide of globalization has brought challenges and pressures to all countries in the world. In order to adapt to the economic globalization and the new competition law and situation, the original mode of administration must be continuously reform, that is, from centralization to decentralization. Decentralization of management is an important symbol of democratization of management.

Decentralization of management requires higher education to reduce government intervention in the management system. The essence of decentralization is to ask the government to decentralization rationally, reduce the scope of activities and improve the management efficiency. In 1970s, many western countries began to pursue Neo liberalism. The government turned from "unlimited government" to "limited government" and the reform of higher education management system. The trend of the reform is to play the role of market mechanism, reduce the direct intervention of the government to higher education, and strengthen the higher education machine. For example, many governments will change the financial aid policy from the original direct investment into competitive investment, which is to fund the performance of the University in accordance with the performance of the University. In the United States, Australia and other countries, some funds are given to students in the form of education vouchers or student loans. By attracting students to get government input, the benefits of educational resources are effectively promoted. In order to encourage the university to improve the quality of running a school, some governments attach importance to professional institutions of the nature of the folk to carry out accreditation and quality assessment of universities, such as the Central Education Review Conference in the UK and the National Higher Education Review Conference, the national higher education and research review in France, and the central education trial of Japan. In addition to the administrative officials and experts and scholars, the members of Parliament include staff, people from all walks of life and representatives of professional groups, so as to ensure the objectivity and professionalism of the review. 


\section{GLOBALIZATION HAS LED TO THE MANAGEMENT OF HIGHER EDUCATION IN CHINA FACE THE NEW DIFFICULTIES.}

Globalization has brought new opportunities to the development of China's higher education management, and it also faces some new difficulties in the reform of China's higher education management.

Border.

A. Plans, Light Market, Heavy Goods and Less People Lead to Biased Management Idea of Higher Education.

Since reform and opening up, China has made great achievements in promoting the development of the socialist market economy. Market mechanism has gradually become the main means of social resource allocation, and the concept of market competition has won popularity among the people. After joining the WTO, the marketization reform of various industries in China has further developed in depth. China has also carried out a local market-oriented reform in the field of higher education. However, due to the particularity of the education industry, some of the reforms still remain on the surface, and there are many biased points in the management concept, which hinders the healthy development of higher education.

First, the management concept of re planning and light market has hindered the formation of the open and fair competition environment of higher education. The main purpose of China's transformation from planned system to socialist market economic system is to create a fair and sound competitive environment. Under the control of the idea of planning the light market, there are still many unfair phenomena in the operation of higher education in China. One is that the system of running higher education is mainly based on government, and the civil capital is often in a disadvantageous position in the competition of participating in the study because of the lack of systematic and powerful legal and policy guarantee. The two is that in the allocation of school resources, to a large extent, it is still the direct investment of the government, and the competitive investment mechanism is not established on the basis of performance. There are obvious differences in obtaining financial allocations and scientific research funding in Colleges and universities. Three, in the allocation of college students, the quality and quantity of the enrollment of different colleges and universities are not fair because of the "Qin" school level, and the four is that students have not yet formed the students' choice of the master, the free conversion of their specialties or schools in the process of learning.

The mechanism leads to the unfairness of college students in the course of education; five, in the employment of graduates, because of the lack of a fair and objective evaluation standard, the employment department can only choose and employ people according to the school level, which causes the unfairness of the graduates' employment.
B. Decentralization, Decentralization, Restraint and Freedom Lead to the Rigidity of Higher Education in the Management System.

Reducing central control of the central government to higher education, giving local government and university autonomy, promoting local government and universities for local conditions, giving full play to their own advantages, showing the characteristics of running schools and improving the competitiveness of schools are the common characteristics of the reform of higher education management system in the response to the globalization of higher education in various countries. Sign. After years of institutional reform, China's higher education management system has basically formed a "two level management of the central and provincial governments and the provincial government management". The provincial government has a substantial autonomy in the setting of colleges and universities, the setting of master's degree points, and the professional setting of colleges and Universities. However, the management means of the government are still lagging behind, and the defects of the management system are increasingly becoming the main obstacles that restrict the innovation and development of our higher education.

C. The Rule of Man, the Rule of Law, and the Neglect of Administration led to the Lag of Higher Education in the Reform of Management System.

On the one hand, economic globalization and cultural diversification have promoted the expansion of university scale and the development of "giant structure", on the other hand, it also promoted the development and heterogeneity of various subcultures of universities. The expansion of scale and cultural diversity will inevitably require changes in the management system of higher education. However, there are two major factors impeding this change in China.

\section{THE MAIN STRATEGY OF CHINA'S HIGHER EDUCATION MANAGEMENT TO MEET THE REQUIREMENTS OF GLOBALIZATION.}

In order to meet the requirements of globalization, China's higher education management reform should follow four major strategies.

\section{A. Establish a "Higher Education" Based on "People First" and "Harmony but Difference".}

It is the common pursuit of higher education of all countries in the era of globalization to respect philosophy, respect for the dominant position of human beings and promote human development. To adapt to this development requirement, China's higher education management must realize the innovation of management concept. First, we must establish a people-oriented management concept. Adhere to the "people-oriented" premise, the premise is to implement the "student oriented", the key is to grasp the "teacher". 
"For the first". "Taking life as the base" is to think of students as the foundation of the existence and development of colleges and universities, and really set up the concept of "everything for students, for all students, for all students". It is to promote the harmonious development of students as the starting point of all educational activities and the foothold of educational reform in the management.

The other is to establish the management concept of "harmony but difference". The so-called "harmony" is to treat foreign management ideas and methods with an open and peaceful attitude, analyze its advantages and disadvantages dialectically, draw on the part of promoting the improvement of China's higher education management level, and realize the complementary advantages and exchange and exchange of Chinese and Western management.

\section{B. Construct a System of Higher Education Management with "Macro Control" and "Independent Flexibility".}

In order to adapt to the fierce competition of globalization, China's higher education management system should further straighten out the relationship between the four actors of the central government, the local government, the universities and the society.

First, the central government and local governments are required to further transform their functions. Secondly, it is necessary to implement the legal person status in universities so as to truly become an independent and flexible school running entity.

\section{Improve the Management System of "Higher Education} and Flexibility" and "Internal and External Links".

"Rigid and soft" is the combination of strict management system and relaxed management atmosphere. Higher education management must have a sound system. The construction of university system should focus on three levels. In the core system, by straightening out the relationship between the University and the government and the society, the concept of independent management and academic management has been put into practice. In the general system, the structure of the current power distribution and the academic power in the operation of the university are strengthened by improving the organizational mechanism of academic democratic management and strengthening the academic power in the operation of the University. The division of labor also has the system of university legal person system, organization and personnel system, education and scientific research system, discipline construction and academic guarantee.

"Internal and external links", that is, the relevant domestic management departments should coordinate communication in the system design, and at the same time, they can link up with the relevant international systems. On the one hand, we should do a good job of "internal communication", that is, the departments of education, commerce, foreign exchange, foreign affairs and entry and exit management, which involve international cooperation in higher education. When revising and perfecting the relevant regulations and systems of their respective management, we should strengthen coordination and communication to avoid the conflict of laws and regulations. On the other hand, on the basis of maintaining national educational sovereignty, it is necessary to take part in the global competition according to the need of higher education to participate in the global competition and the People's Republic of China education law, the People's Republic of China higher education law, the People's Republic of China Teacher Law and the Chinese people. The laws and regulations such as the private education promotion law of the civil Republic and the regulations and regulations of the Chinese and foreign cooperation in running schools are revised, perfected and enacted, and according to the relevant regulations and standards of the international higher education coordination organization.

The internationalization of China's higher education should be prepared with a clear understanding of its own foundation and the ability to lead the development; to further optimize the international student training system, to improve the quality of the training of the overseas students in China, and to cultivate a large number of international talents who know China, friends, and love China. At the same time, the internationalization of China's higher education should serve the global development, promote China's integration into the global research circle, increase the international scientific research cooperation, and make China take the lead in the world's top scientific and technological achievements, serve the global governance, and expand the ability to participate in global governance by participating in global higher education governance. In order to make China play the role of global policy participants, advocates, even leading. China has made Chinese higher education truly enter the international community and bloomed on the international stage.

\section{References}

[1] Internationalization and Trade of Higher Education---Challanges and Opportunities[R].Paris:OECD,2004. 